\title{
A New Species of the Varunid Crab Genus Gopkittisak (Crustacea: Decapoda: Brachyura: Grapsoidea) from the Ryukyu Islands
}

\author{
Tomoyuki Komai \\ Natural History Museum and Institute, Chiba, \\ 955-2 Aoba-cho, Chuo-ku, Chiba, 260-8682 Japan \\ E-mail:komai@chiba-muse.or.jp
}

(Received 20 April 2011; Accepted 12 June 2011)

\begin{abstract}
A new species of the varunid crab genus Gopkittisak Naruse and Clark, 2009, G. angustum sp. nov., is described on the basis of seven specimens from intertidal sand flats at Iriomote Island, Ryukyu Islands, Japan. It is close to its sole congener $G$. gallardoi (Serène and Soh, 1976), but the different shapes of the carapace and male abdomen, as well as the setal pattern of the propodus of the fourth pereopod and the coloration in life, distinguish the new taxon from $G$. gallardoi.

Key Words: Crustacea, Decapoda, Brachyura, Varunidae, Gopkittisak, new species, Japan.
\end{abstract}

\section{Introduction}

The varunid crab genus Gopkittisak was established by Naruse and Clark (2009) to accommodate Asthenognathus gallardoi Serène and Soh, 1976, a species which had until then been traditionally placed in the subfamily Asthenognathinae of the family Pinnotheridae (Serène and Soh 1976; Ghani and Tirmizi 1991; Jiang et al. 2007; Ng et al. 2008). This species was originally described on the basis of a single ovigerous female from the Andaman Sea, although Serène and Soh (1976) also identified a single female specimen from Nhatrang Bay, Vietnam, as belonging to their new taxon. Since the original description, this species has been recorded from Pakistan (Ghani and Tirmizi 1991; Tirmizi and Ghani 1996), the Gulf of Tonking in the South China Sea (Jiang et al. 2007), and the Philippines (Naruse and Clark 2009).

While sampling of shallow-water decapod crustaceans in the Yaeyema Islands, southern Ryukyu Islands, Japan, I collected some varunid crabs from burrows in intertidal sand flats at Iriomote Island. Initially, these specimens were tentatively identified as Asthenognathus gallardoi, but direct comparison with two topotypic female specimens collected by myself from Phuket, Thailand, revealed that the Japanese specimens are specifically distinct. In this paper, I describe and illustrate a new species, $G$. angustum, on the basis of seven specimens, including six males and one female.

The material examined in this study is deposited in the Natural History Museum and Institute, Chiba. The size of specimens is indicated by the carapace length $\times$ carapace width in millimeters. 


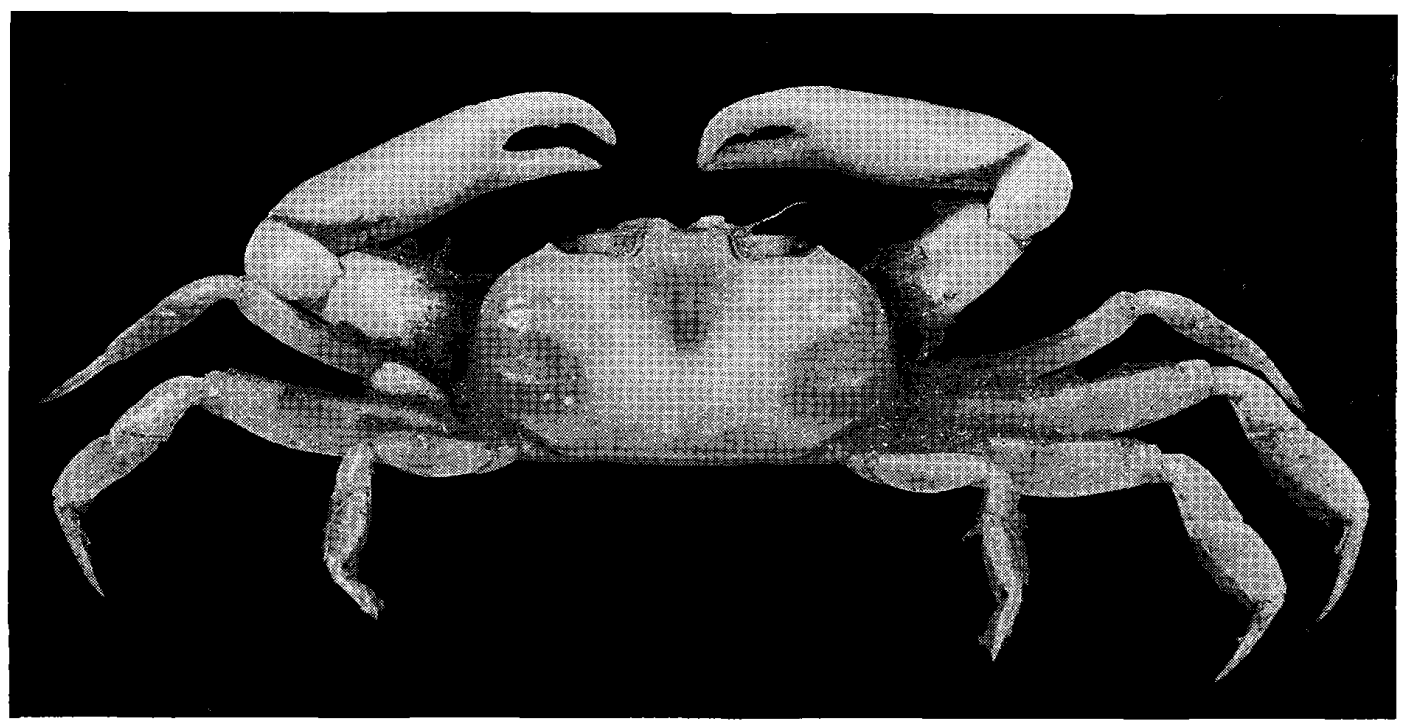

Fig. 1. Gopkittisak angustum sp. nov., holotype, male $(5.1 \times 9.1 \mathrm{~mm})$, CBM-ZC 8417 , entire animal in dorsal view.

\section{Taxonomy}

Gopkittisak angustum sp. nov.

(Figs 1-4)

Gopkittisak gallardoi: Naruse and Clark 2009: 63 (in part), fig. 3B (not Asthenognathus gallardoi Serène and Soh, 1976).

Material examined. Holotype: CBM-ZC 8417 , male $(5.1 \times 9.1 \mathrm{~mm})$, Hinai beach, Uehara, Iriomote Island, Yaeyama Islands, Ryukyus, burrow in sand flat, $11 \mathrm{July}$ 2002, digging with small scoop, coll. T. Komai. Paratypes: CBM-ZC 7189, 4 males $(2.8 \times 4.6$ to $4.5 \times 7.8 \mathrm{~mm})$, Sonai beach, Iriomote Island, burrows in sand flat, 9 July 1998, digging with small scoop, coll. T. Komai; CBM-ZC 10438, 1 male $(4.5 \times 8.0 \mathrm{~mm})$, 1 female $(4.5 \times 7.9 \mathrm{~mm})$, same data as holotype. Comparative material: Gopkittisak gallardoi, CBM-ZC 10225, 2 females $(3.6 \times 7.2,4.4 \times 9.6 \mathrm{~mm})$, Ko Sirei, Phuket, Thailand, burrows in intertidal sand flat, December 2009, yabbie pump, coll. T. Komai.

Description. Male. Carapace (Figs 1, 2A) elliptical, 1.60-1.76 times wider than long; dorsal surface slightly convex both longitudinally and transversely, smooth, regions hardly demarcated, but trace of cervical groove evident medially; anterior part of branchial region with 1 or 2 short, transverse, granulate ridges and oblique rugae; posterrior part of dorsal surface with trace of transverse ridge across cardiac region, connected laterally with oblique granulated ridge extending to lateral margin of carapace, forming posterolateral facet. Front barely deflexed (Fig. 2B), nearly as wide as orbit; frontal to upper orbital margin rimmed, non-granulated, fronto-orbital margin as wide as posterior margin of carapace, frontal margin nearly straight; external orbital angle blunt, slightly produced anteriorly (Fig. 2C); lower orbital margin slightly crenulate, extending laterally along anterolateral margin (Fig. 2B, D); inner orbital tooth small, bluntly pointed, falling far short of 


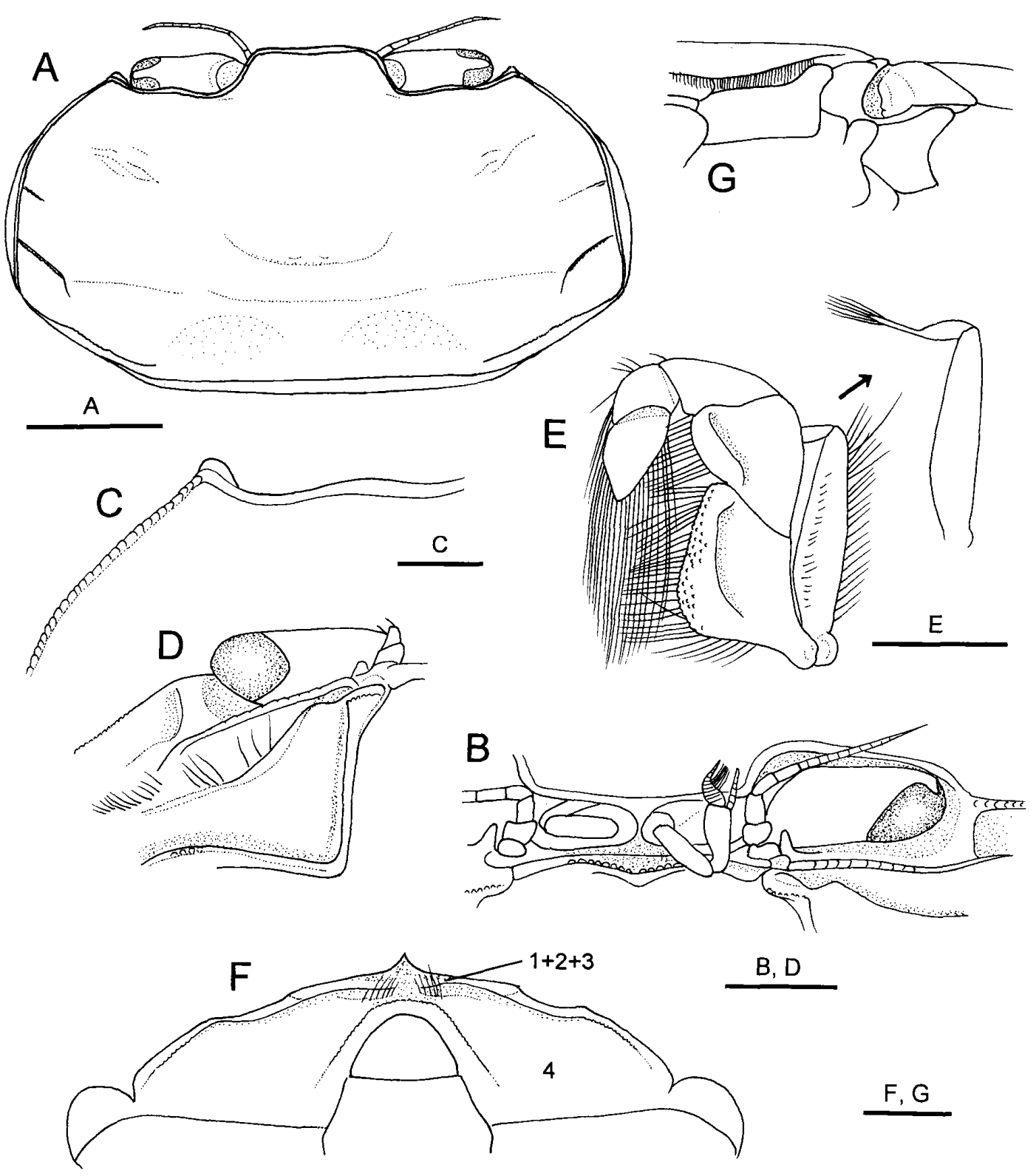

Fig. 2. Gopkittisak angustum sp. nov., holotype, male $(5.1 \times 9.1 \mathrm{~mm})$, CBM-ZC 8417. A, Carapace, eyes and antennae, dorsal view (setae omitted); B, frontal region of carapace and left cephalic appendages, anterior view; C, left external orbital angle and anterior part of anterolateral margin, dorsal view; $\mathrm{D}$, right pterygostomial part of carapace and right eye, ventral view; E, left third maxilliped, ventral (outer) view, with detail of exopod, ventral view; F, anterior three thoracic sternites and telson $(1+2+3$ : fused first to third sternites; 4 , fourth sternite), ventral view; $\mathrm{G}$, right eighth thoracic sternite, posterior view. Scale bars: $2 \mathrm{~mm}$ for A; $1 \mathrm{~mm}$ for $\mathrm{C}-\mathrm{G}$; $0.5 \mathrm{~mm}$ for $\mathrm{B}$.

lateral frontal angle (Fig. 2B). Anterolateral margin broadly arcuate, delimited by minutely granulate ridge running from external oibital angle to posterolateral angle (Fig. 2A, C). Epimera partially visible in dorsal view (Fig. 2A). Pterygostomial region (Fig. 2D) with low, sinuous ridge extending from anterolateral angle of 
buccal frame, this ridge bordered by plumose setae. Lateral margin of buccal frame (Fig, 2D) with distinct, smooth carina. Epistome (Fig. 2B) very short, obtusely triangular, bordered by granules along margins; surface shallowly concave.

Eye (Fig. 2A, B, D) about 0.2 times as long as carapace width, mobile; eyestalk slightly widened basally; cornea well-developed, darkly pigmented. Antennular peduncle (Fig. 2B) folded transversely; basal segment large, transversely ovate. Antennal peduncle (Fig. 2B) standing vertically, reaching lateral frontal angle by third segment; flagellum reaching nearly to external orbital angle.

Third maxilliped (Fig. 2E) with relatively narrow ischium-merus, filling less than two-thirds of buccal cavern when closed. Ischium subrectangular, longer than merus measured along mesial margin; outer face coarsely granulated mesially, having distinct submarginal ridge along mesial margin; merus subtriangular with articulation to ischium strongly oblique, bearing distinct submarginal ridge on outer face along mesial margin. Carpus articulated to lateral half of distal margin of merus, somewhat widened distally. Propodus wider than long, articulated to distal end of carpus, bearing long setae on extensor margin. Dactylus subtriangular, articulated to distal end of propodus, bearing elongate setae on extensor and flexor margins. Exopod moderately slender, tapering distally, falling short of distal margin of merus; flagellum well develooped.

Thoracic sternum very wide, nearly smooth, median part anterior to sternoabdominal cavity slightly concave to accommodate setae on dactyli of third maxilliped, bearing scattered setae. First to third thoracic sternites fused (Fig. 2F); showing as transverse rim bordering anterior part of fourth sternite. Fourth sternite with granulated rim along sterno-abdominal cavity (Fig. 2F). Sternal condyle located on distolateral end of fifth sternite. Penis sternal, appearing from distal end of eighth throacic sernite.

Chelipeds equal or subequal, similar (Fig. 1). Ischium short, smooth. Merus (Fig. 3C) about twice as long as wide; dorsal surface smooth, with scattered short setae proximally; inner surface slightly concave, inner dorsal margin with row of granules and thick plumose setae, inner ventral margin with row of small tubercles. Carpus (Fig. 3B) less than half as long as palm, lacking a prominent spine or tooth, its surfaces nearly smooth; outer face strongly convex. Chela (Fig. 3A, B) large, about 2.5 times as long as high measured along dorsal margin, length about 0.7 of carapace width; fingers meeting at tip, leaving wide hiatus when closed; ventral margin slightly sinuous. Dactylus shorter than palm, naked, noticeably curving, terminating in subacutely pointed tip; outer face sparsely punctate, with trace of longitudinal median ridge in proximal half; dorsal surface rounded; cutting edge with row of small, rounded teeth, those at midlength larger than others. Fixed fin-

Fig. 3. Gopkittisak angustum sp. nov. A-I, Holotype, male $(5.1 \times 9.1 \mathrm{~mm})$, CBM-ZC 8417 ; J, paratype, female $(4.5 \times 7.9 \mathrm{~mm})$, CBM-ZC 10438. A, J, Right chela, outer (anterior) view; B, right chela and carpus, dorsal view; $\mathrm{C}$, merus of right cheliped, dorsal view; $\mathrm{D}$, right second pereopod (first ambulatory leg), posterior view; E, right third pereopod (second ambulatory leg), posterior view; F, right fourth pereopod (third ambulatory leg), posterior view (setae partially omitted); G, same, propodus, flexor view, showing setation; $\mathrm{H}$, right fifth pereopod (fourth ambulatory leg), posterior view; I, same, dactylus, posterior view (setae omitted). Scale bars: $1 \mathrm{~mm}$ for A-H, J; $0.5 \mathrm{~mm}$ for I. 

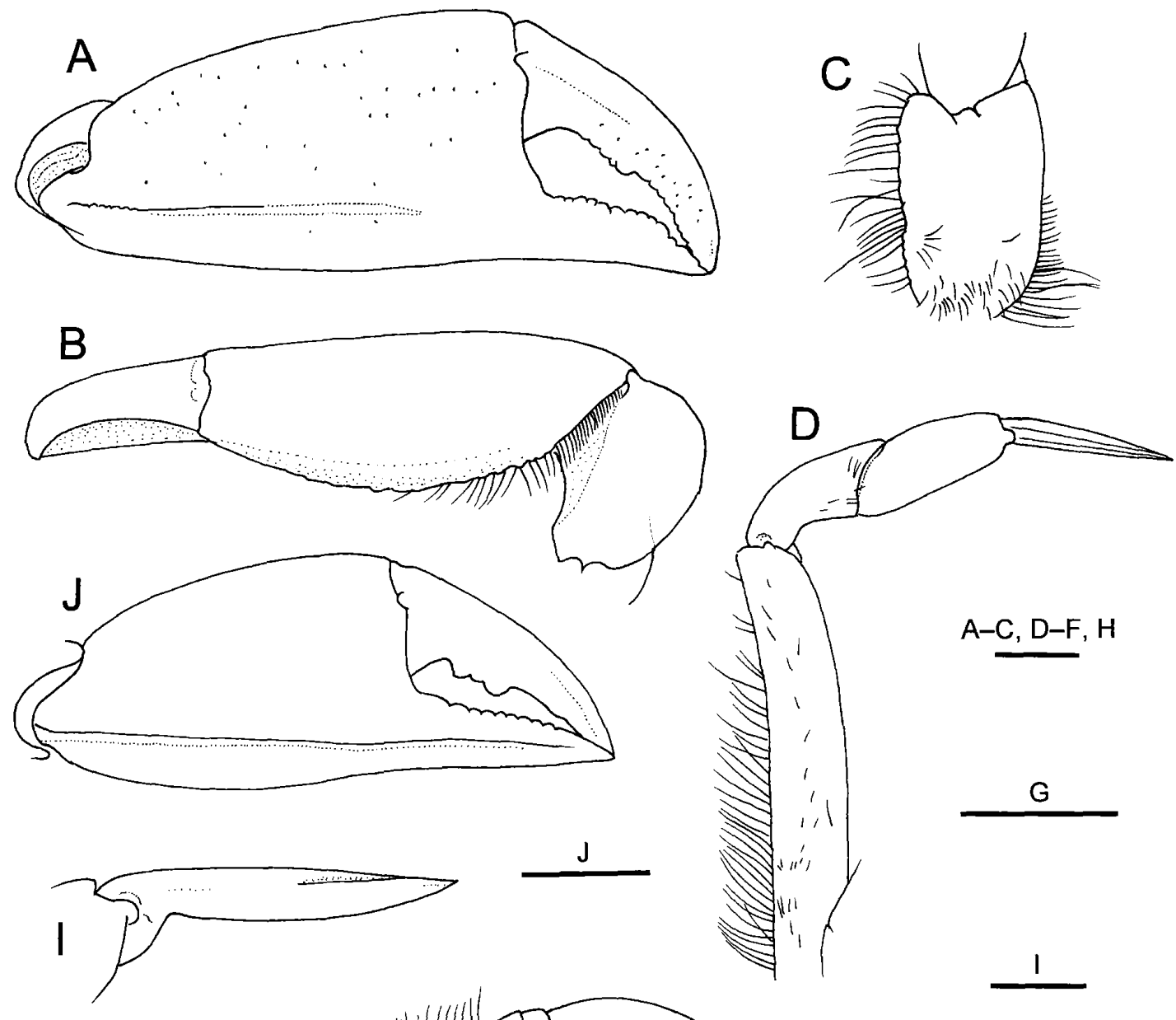

A-C, D-F, H

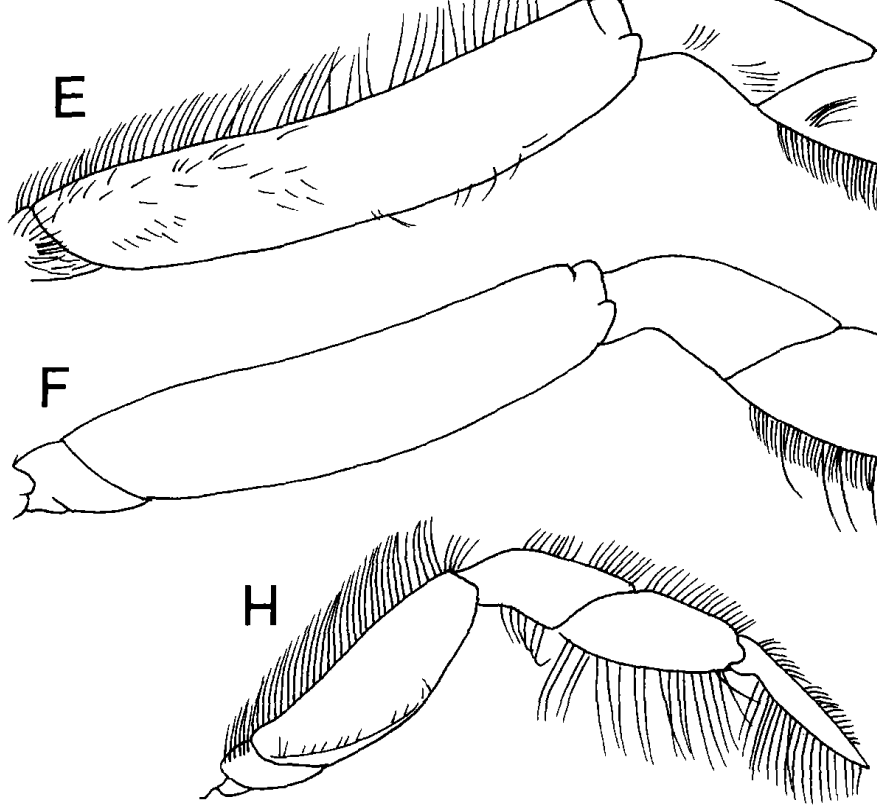

1

G
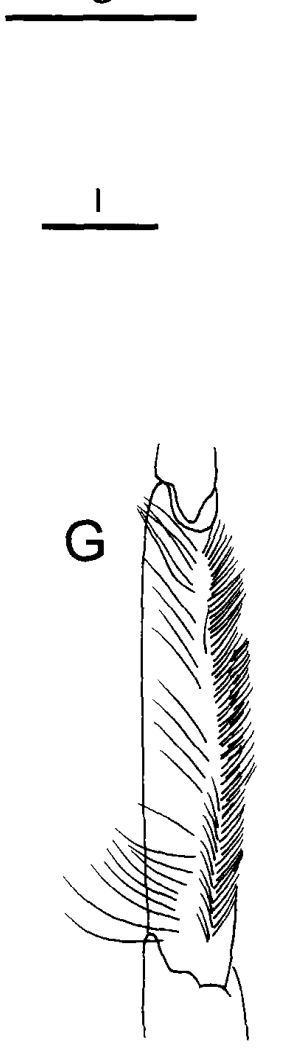
ger nearly straight, with row of small, blunt teeth on cutting edge. Palm approximately twice as long as high at most, becoming higher distally; dorsal surface rounded, very slightly convex in outline; outer face sparsely punctate, with weak ventral longitudinal ridge not extending to fixed finger; inner face convex, with sparse granules and rows of plumose setae dorsally adjacent to articulation to carpus; ventral margin sinuous in outer view.

Ambulatory legs (Figs 1, 3D-F, H) moderately slender, noticeably compressed, third and fourth pereopods (second and third ambulatory legs) subequal in length, much longer than second and fifth pereopods (first and fourth ambulatory legs), fifth pereopod shortest; length of fourth pereopod about 1.5 times carapace width. Ischia with smooth on every surface. Meri elongate, slightly recurved, each with subdistal transverse groove and row of setae on upper (extensor) surface; upper (extensor) and lower (flexor) surfaces non-carinate, nearly smooth or weakly granulated, upper surface with numerous setae; posterior and anterior surfaces nearly smooth; merus of fourth pereopod about 4.5 times longer than wide; merus of fifth pereopod with weak submarginal ridge on posterior face along ventral (flexor) margin. Carpi widened distally, smooth on surfaces, extensor margin rounded (second) or distinctly carinate (third to fifth). Propodi longer than (second to fourth pereopods) or subequal in length (fifth pereopod) to carpi, as measured along extensor margin; extensor margins glabrous, distinctly carinate; flexor magins glabrous (second pereopod) or bearing numerous plumose setae (third to fifth pereopods). Dactyli slightly longer than propodi, as measured along extensor margins, each gradually tapering to acute apex, sligthly curved and subconical with six longitudinal carinae (second to fourth pereopods) or slightly recurved and strongly flattened (fifth pereopod).

Abdomen (Fig. 4A) moderately wide, first and second somites very short, first somite with transverse ridge extending across entire width. Third somite wider than second, but slightly narrower than first. Fourth to sixth somites fused, with not trace of suture on outer face; proximolateral margin of sixth somite forming low but distinct convexity, with socket for sternal condyle on inner face. Telson (Fig. 4A) roundly triangular, slightly wider than long.

First gonopod (Fig. 4B) stout, subtriangular in cross section, reaching suture between third and fourth thoracic sternites, nearly straight in sternal (ventral) view; chitinous terminal process (Fig. 4B-C) subtruncate distally, slightly curving dorsally, shallowly concave on dorsal side, obscured by numerous stiff setae; obtuse convexity proximomesial to terminal process. Second gonopod (Fig. 4E) small, moderately stout, slightly twisted; dorsal margin thin, laminar.

Female. Generally similar to adult males, but differing in following points: chela (Fig. 3J) proportionally smaller, length 0.5 times carapace width. Ambulatory legs relatively stout, i.e., merus of fourth pereopod 2.2 times longer than wide. Abdomen (Fig. 4F) about 1.3 times as wide as long, covering thoracic sternum; sixth abdominal somite about 5.5 times wider than long measured along midline; telson subrhomboidal, about 2.8 times wider than long, about 0.4 times as wide as sixth somite. Vulvae widely separated, papilla-like.

Coloration in life. Carapace generally gray or beige, with scattered brown dots; chelipeds and ambulatory legs generally gray (Naruse and Clark 2009, fig. 3b).

Distribution. Known only from Iriomote Island, Yaeyama Islands, Ryukyus, and Panglao Island, Philippines; intertidal sand flats. 

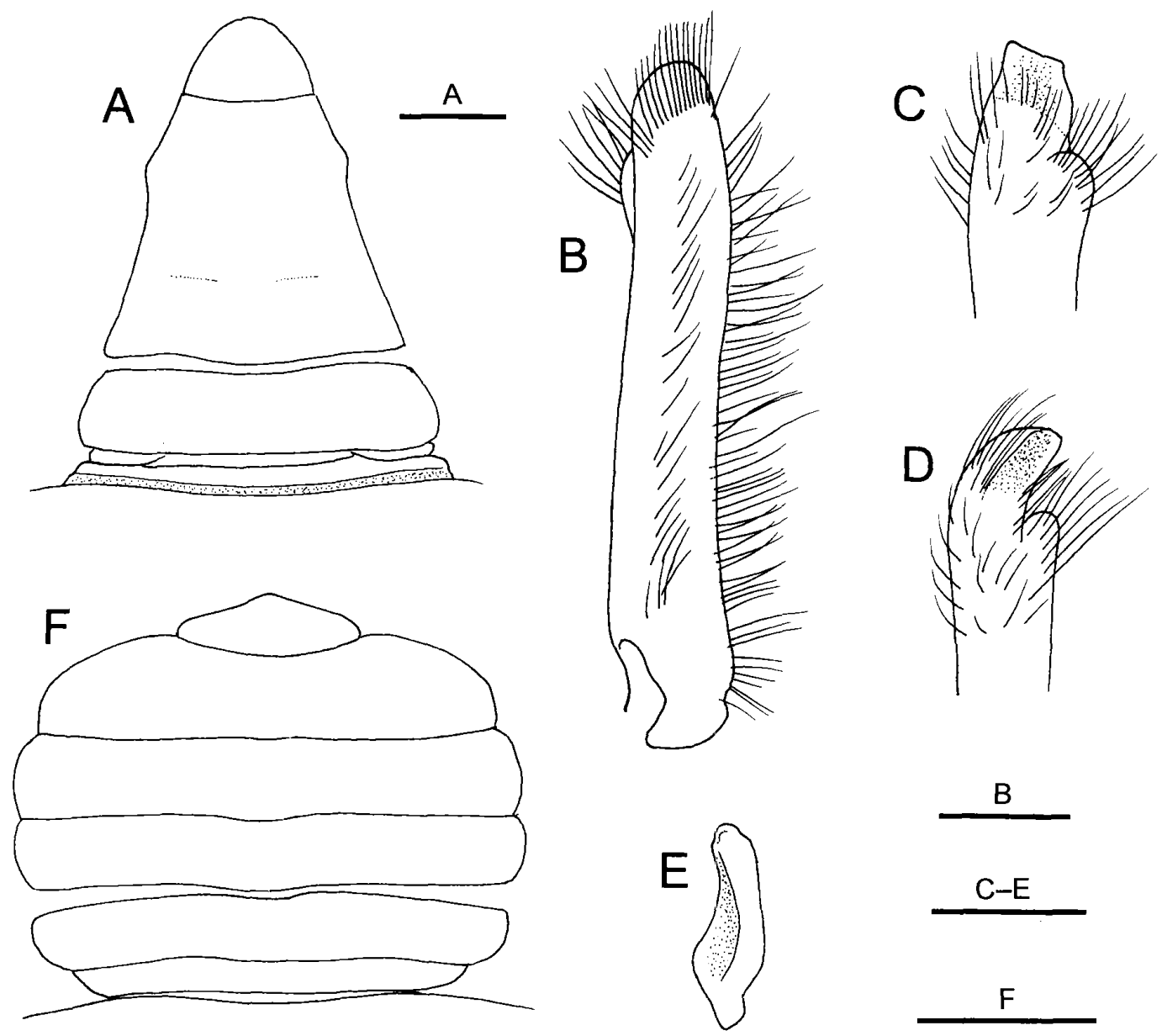

Fig. 4. Gopkittisak angustum sp. nov. A-E, Holotype, male $(5.1 \times 9.1 \mathrm{~mm})$, CBM-ZC 8417 ; F, paratype, female $(4.5 \times 7.9 \mathrm{~mm})$, CBM-ZC 10438. A, F, Abdomen, outer (ventral) view; B, left first gonopod, ventral view; $\mathrm{C}$, same, distal part, dorsal view; $\mathrm{D}$, same, lateral view; $\mathrm{E}$, left second gonopod. Scale bars: $2 \mathrm{~mm}$ for $\mathrm{F} ; 1 \mathrm{~mm}$ for A; $0.5 \mathrm{~mm}$ for B-E.

Remarks. Gopkittisak angustum sp. nov. is similar to its sole congener, G. gallardoi, but the new species is easily distinguished by the proportionally narrower carapace (1.6-1.8 times as wide as long versus 2.0-2.2 times) and the relatively narrower female abdomen (for example, the sixth abdominal somite about 5.5 times as wide as long versus 6.5-6.6 times in G. gallardoi). Futhermore, the transverse ridge on the posterior half of the carapace is less distinct in $G$. angustum than in G. gallardoi (cf. Figs 2A, 5A). The setation of the propodi of the third and fourth pereopods differs between the two species. In G. angustum, the flexor surface of the propodus of these pereopods has numerous setae in addition to a row of dorsally directed setae on the dorsal side (Fig. 3E, G) whereas in G. gallardoi, only the row of dorsally directed setae is present while most of the flexor surface is glabrous (Fig. 5B, C). The color in life also seems to be different between the two species. As Naruse and Clark (2009, fig. 3b) described for their material from Panglao Island (as G. gallarodi, see below), the dorsal surface of the carapace of G. angustum is gray or beige with scattered brown dots; in $G$. gallardoi, it is mottled brown with 


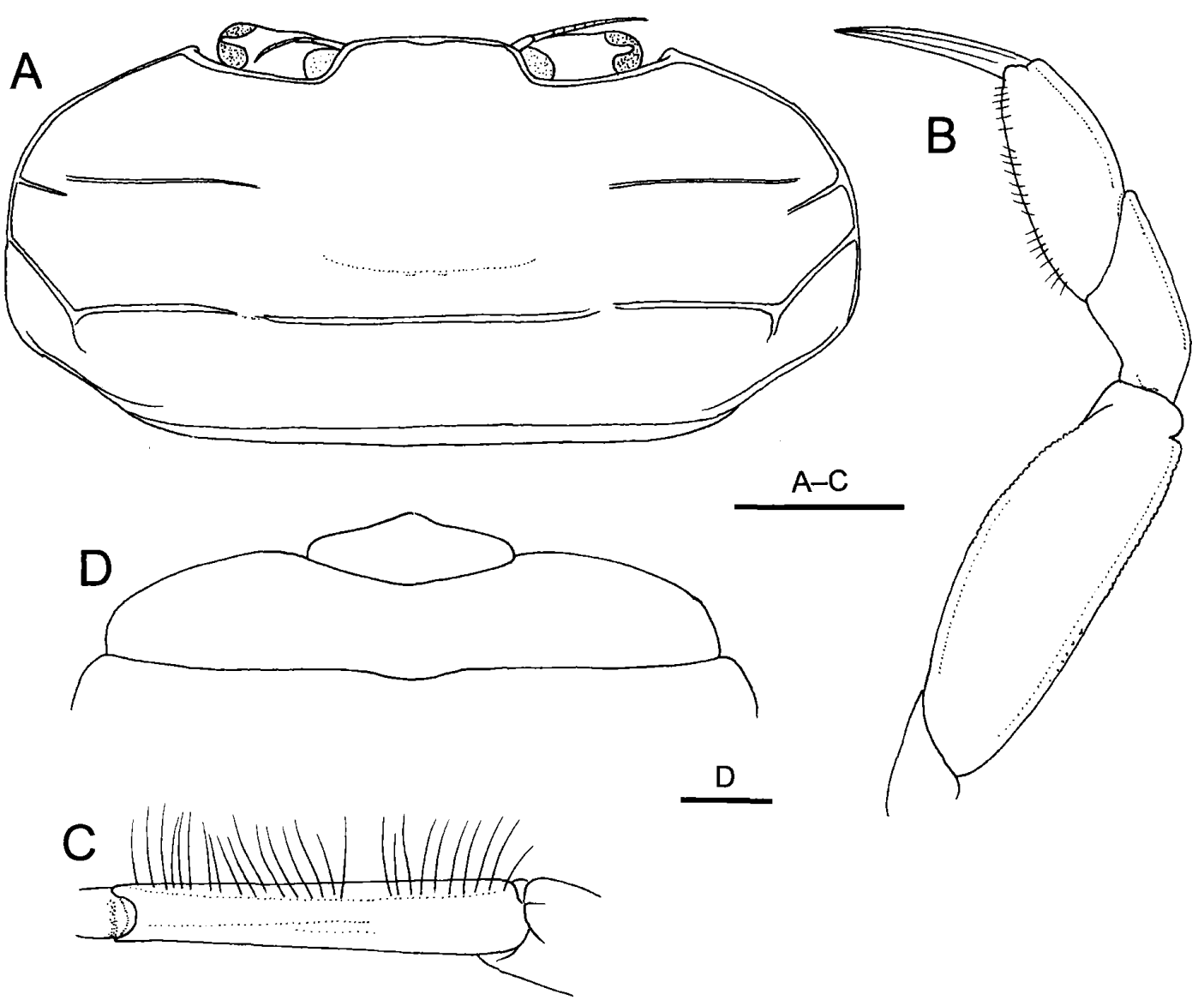

Fig. 5. Gopkittisak gallardoi (Serène and Soh, 1976), female (4.4×9.6 mm), CBM-ZC 10225. A, Carapace, eyes and antennae, dorsal view; B, left fourth pereopod (third ambulatory leg), posterior view; C, same, propodus, flexor view, showing setation; D, sixth abdominal somite and telson, outer (ventral) view. Scale bars: $2 \mathrm{~mm}$ for A, B; $1 \mathrm{~mm}$ for C, D.

two white spots anteriorly (Naruse and Clark 2009, fig. 3a).

The specimens reported from Panglao Island agree better with the new species than with G. gallardoi in carapace shape and the setation of the propodi of the third and fourth pereopods. Consequently, Naruse and Clark's (2009) records of $G$. gallardoi from this locality should be referred to $G$. angustum instead. Other records of G. gallardoi from the western Pacific (Serène and Soh 1976; Jiang et al. 2007) need to be verified. A specimen from the Gulf of Tonking, southern China, identified and figured as G. gallardoi by Jiang et al. (2007: 78, 81, fig. 1, as Asthenognathus), is actually more similar to $G$. angustum in the shape of the carapace, but the setation of the propodi of the third and fourth pereopods is not shown on their figure. It is difficult to determine the identity of these Chinese specimens without examination.

Although the present data suggest that the new species is rather widely distributed in East and Southeast Asian waters, its habitat in intertidal sand flats is rather fragile with respect to human activities. Despite extensive sampling in the Ryukyu Islands, I have encounterd this species only at Iriomote Island, which suggests that the habitat of $G$. angustum is narrowly restricted. 
Etymology. From the Latin angustus (=narrow), in reference to the relatively narrow carapace compared with the sole congeneric species, G. gallardoi.

\section{Acknowledgments}

I thank my wife Satoko Komai for her help in the field survey. Thanks are also extended to the two referees who reviewed the manuscript.

\section{References}

Ghani, N. and Tirmizi, N. M. 1991. Rediscovery of Asthenognathus gallardoi Serène \& Soh, 1976, from Pakistan (northern Arabian Sea) with description of the male. Crustaceana 61: 100-102.

Jiang, W., Chen, H.-L. and Liu, R.-Y. 2007. New records of two species of genus Asthenognathus (Crustacea: Decapoda: Pinnotheridae) from China seas. Oceanologia et Limnologia Sinica 38: 77-83.

Naruse, T. and Clark, P. F. 2009. Establishment of a new genus for Asthenognathus gallardoi Serène \& Soh, 1976 within Gaeticinae Davie \& Ng, 2007 (Crustacea: Decapoda: Brachyura: Varunidae). Zootaxa 1987: 61-68.

Ng, P. K. L., Guinot, D. and Davie, P. J. F. 2008. Systema Brachyurorum: Part 1. An annotated checklist of extant brachyuran crabs of the world. Raffles Bulletin of Zoology, Supplement 17: 1-286.

Serène, R. and Soh, C. L. 1976. Brachyura collected during the Thai-Danish Expedition (1966). Phuket Marine Biological Center Research Bulletin 12: 1-37, figs 1-28, pls 1-8.

Tirmizi, N. M. and Ghani, N. 1996. Marine Fauna of Pakistan: 5. Crustacea: Brachyura: Brachyrhyncha Part I (Xanthidae, Goneplacidae, Pinnotheridae, Ocypodidae, Grapsidae). Centre of Excellence in Marine Biology, University of Karachi, Karachi, 188 pp. 